\title{
Miranda
}

Revue pluridisciplinaire du monde anglophone /

Multidisciplinary peer-reviewed journal on the English-

speaking world

$8 \mid 2013$

In Umbra Voluptatis : Shades, Shadows, and their

Felicities / Film Adaptations, New Interactions

\section{Closure and Happy Endings in Janet Frame's The Lagoon and Other Stories}

Armelle Parey

\section{OpenEdition}

Journals

Electronic version

URL: http://journals.openedition.org/miranda/3395

DOI: 10.4000/miranda.3395

ISSN: 2108-6559

\section{Publisher}

Université Toulouse - Jean Jaurès

\section{Electronic reference}

Armelle Parey, "Closure and Happy Endings in Janet Frame's The Lagoon and Other Stories", Miranda [Online], 8 | 2013, Online since 28 June 2013, connection on 16 February 2021. URL: http:// journals.openedition.org/miranda/3395 ; DOI: https://doi.org/10.4000/miranda.3395

This text was automatically generated on 16 February 2021.

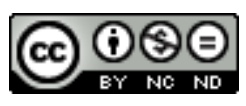

Miranda is licensed under a Creative Commons Attribution-NonCommercial-NoDerivatives 4.0 International License. 


\title{
Closure and Happy Endings in Janet Frame's The Lagoon and Other Stories
}

\author{
Armelle Parey
}

Closure and happy endings are not phrases that immediately come to mind when looking at Janet Frame's stories. The ending is usually understood to be a key element if not THE key element in the overall impact of a short story, the point at which the whole story is aimed. ${ }^{1}$ But some of Frame's short texts in her first collection The Lagoon and Other Stories (1951) are marked by low narrative content which may lead to cancelling notions of beginnings, middles and ends, following the twentieth-century tendency to discard patterns of closure and Aristotelian requirements. ${ }^{2}$ Like modernist stories, a number of Frame's texts are indeed structured around an epiphany (Bazin 2010, 14-15): everything centres around a revelation that upsets the dynamics of the world or of the character presented so far. A consequence of this particular structure is that it may remove the regular emphasis on the end of the short story: in "Swans", for instance, the revelation occurs during the day trip and the actual ending-the return home with the cat's death-thus reads as anti-climactic ${ }^{3}$. As Winston Rhodes says of the title story "The Lagoon", "here as elsewhere the story that is told is one of 'being' rather than one of 'doing"' (119). ${ }^{4}$ Indeed, not much happens in some of Frame's stories ${ }^{5}$ that often focus on a minor event set in the past: "[t]he incidents she records may often seem trivial and scarcely significant for the slightest sketch" (Winston Rhodes 119). Critics have consequently suggested other names for these short texts, such as "sketch" (Winston Rhodes 119), "lyric poem"' (see Richards), "fable" (Weiss 45) or "prose poem" (Lorre 2007, 264), which may suggest a different emphasis on endings. The whole collection, as Vanessa Guignery aptly puts it, is "marked by a sense of ungraspability" (306), ${ }^{7}$ which may find its expression in the reader's difficulty to reach a sense of closure-"the sense of stable conclusiveness, finality or 'clinch"' (Herrnstein Smith 2), that which "allows the reader to be satisfied by the failure of continuation or, put another way, [...] creates in the reader the expectation of nothing" (Herrnstein Smith 33). For Patrick Evans considering Frame's novels, this is so because Frame the experimentalist cannot satisfy herself with the usual mechanics. He thus notes her "refusal to set up plot tensions, and the resulting need for an arbitrary conclusion that 
will not be resolved by the mechanics of a plot" (296). Yet, when discussing the endings of the novels, Alice Braun finds that Frame does follow a certain logic, albeit an alternative one, and she points to a significant tension in Frame's writing:

There is indeed a paradox at the heart of Frame's writing, the conjugation of two major opposing forces: one of deconstruction that tends to question and decentre such notions as language, fiction and authority, and another force of synthesis that structures, binds and makes sense. $(2011,107)$

While being distrustful of order and authority, it appears that Frame does not stop her stories in mid air or on scenes "usually presented without authorial commentary" as Henry James famously did (Torgovnick 11) but nevertheless offers structured endings. This paradox is the starting-point for this study of Frame's first collection of short stories. I will first explore this tension by considering how the clausula-i.e. the actual concluding lines-relates to the whole story. In other words, does it contribute (or not) to this feeling of ungraspability that can be interpreted as rejection of authority? Conversely, does a formal ending always lead to closure? ${ }^{8}$ Second, I will focus on how the self-reflexive dimension of some stories contributes or not to illustrating Frame's idea of closure. Finally, I will conclude with a study of the unlikely presence in Frame's early stories of what is often presented as the epitome of closure, i.e. happy endings (as the temporary privilege of childhood).

\section{Is there an end(ing)?}

3 The (double) question above arises from the fact that in several instances, the formal end clashes with the floating dimension of a number of Frame's stories. The world represented in the stories is indeed fragmentary, with an often fluctuating narrative voice expressed in the use of free indirect style to slide from one viewpoint to another to the effect of rejecting the totalising voice of authority that would permeate omniscience. The paradox of Frame's stories rests in the contrast between the inconclusinevess of the stories and the binding force of their overdetermined ending. "The Lagoon", for instance, in which the narrator returns to a childhood haunt and hears about a possible family murder there, denies the reader any certainty, any ability to reach a conclusion as to what the "true" story is. The text nevertheless has a very strong formal ending with the near repetition of the opening words in the clausula:

At low tide there is no lagoon. Only a stretch of dirty grey sand. I remember we used to skim thin white stones over the water and catch tiddlers in the little creek near by and make sand castles. This is my castle we said, you be Father I'll be Mother and we'll live here and catch crabs and tiddlers for ever... (7)

Contrasting openly with the unresolved mystery of the lagoon, the last paragraph conveys a sense of closure because the reader recognises elements from the story and has the impression that a cycle (or circle) has been completed, with a return to the starting point. Yet, the clausula itself displays tension between closure and inconclusiveness. This last paragraph is indeed a compilation of sentences read before and this difference in the repetition effectively "opens up the story and has a liberating effect" (Lorre 2007, 261). Along with the suspension marks at the very end, this may challenge and erode the sense of conclusiveness but it certainly does not destroy it. So, a circular pattern, "one of the most common closural patterns" (13) for Torgovnick when studying novels, ${ }^{9}$ seems to be both existing and broken in "The Lagoon". In fact, another one of Torgovnik's phrases applies to some of Frame's stories which present a 
similar (apparent) pattern of circularity when the final words echo (or are identical to) those of the title ${ }^{10}$-"incompletion": "incomplete closure includes many aspects that suggest circular or parallel closure, but omits one or more crucial elements necessary for full circularity of parallelism" (13).

5 In "Miss Gibson-And the Lumber-Room", the clausula picks up the title which it seems to explain. In this story in the shape of a letter, the narrator goes back with undisguised satisfaction over an essay written as a child. The avowed purpose of the story quickly appears dubious: whereas she claims she wants to correct her lie, she seems to fall back into the same imaginative mode as when writing the essay as a child. Note for instance the imbrication or merging of the levels of narration striking in: "Well, I went home and wrote my essay. We lived in a large house at the time" (144). Whereas the first one is to be attributed to the author of the letter narrating the past, the second one is not. While the first sentence is about her younger self, the second one is written as her younger self. With no other break in the text than a new sentence, the narrator goes into the mode of her younger self fantasising her childhood with the change of pronoun from "I" to "we" marking the return to fancy. Besides, she knows that the teacher never believed what was written in the essay-she wrote "highly improbable"(146) so there is no real need to go back over it. In the last paragraph however, the narrator seems to abandon all pretence to tell in a direct way what her childhood was really like. The very last line, echoing the title, sounds as the last blow, revealing the magnitude of the lie: "and Miss Gibson, if you really want to know, we didn't even have a lumber-room" (147). In fact, the lie is revealed not to be hers but the teacher's who gave an inadequate essay topic in the first place. ${ }^{11}$ From the very formal closure with the impression of circularity derives in fact the narrator's freedom when she eventually breaks the mould.

6 Thus, "A Beautiful Nature"-about lonely Edgar amidst unsupportive fellow lodgers in a boarding-house-ends with

Mrs Michael, who was jigging a little tin of soap up and down in the water to make a good lather, giggled with others, and then smiled dutifully. She belonged to the Church. He has a beautiful nature, she said profoundly (114).

7 The domineering sense in the end is closure: Mrs Michael's words are meant to sum up Edgar's character and they do. There is yet an ongoing tension between closure and rupture of circularity which suggests resistance and freedom. Neutral in the title, the phrase "a beautiful nature" reappears in the clausula now laden with hypocrisy and emptied of meaning when placed in the mouth of a sententious and self-righteous character..$^{12}$ The meaning of the title is elucidated but there is no perfect adequation (a question gets its answer) because, as said above, the phrase takes on a particular value -different from the one assigned by the reader at first-when uttered by the character at the end. The discrepancy between the beginning and the end which breaks the perfection of the circle and the underlying hypocrisy denounce the labelling of people expressed in the clausula. Closure is indirectly associated with limitation and reduction.

8 In these stories, closure is formally conveyed by a circular pattern which yet contains an element that opens up the story at the same time in various degrees. But it is not so in the hospital stories where the pattern of circularity is quite marked and enhances the feeling of limitation. Closure then actually means enclosure. Such is the case of "The Bedjacket" in which Nan means to offer something out of the ordinary to Nurse 
Harper for Christmas and embarks on knitting a bedjacket even though "she had never knitted a garment in her life" (37). Nan completes her knitting but she is suffused with feelings for the beautiful finished product which she is eventually unable to part from. More than Nan's achievement, the story ends on a deflecting note:

And the next afternoon which was shopping afternoon, Nan who was not allowed to go shopping sent one of the patients to buy something for her, a box of soap and a face-cloth wrapped in cellophane, a Christmas present for Nurse Harper (39).

Nan is no longer allowed to go out at all and is preparing to offer a commonplace present, a readymade gift already "wrapped in cellophane" when she was aiming for something personal-"I wonder what Nurse Harper would like most in all the world" (36). The fact that Nan ends up offering the very thing she did not want to offer conveys circularity, lack of progress, imprisonment and defeat. In "Snap-Dragons", in which the protagonist is about to leave the hospital with her mother, the final word echoes the title, thus conveying circularity and closure. This circular structure clearly indicates enclosure, all the more so as the flower acts as a metaphor for a prison, whether it be the hospital or home. "The Park" is the epitome of circularity as enclosure as it actually depicts hospital patients walking around a park, immediately qualified by its "brown picket fence" (173). The park is first presented from the outside, possibly by one of the doctors, definitely by somebody who does not belong as indicated by the deictics: "That is the park,' he said. 'They walk there" (173). ${ }^{13}$ The firstperson narrator enters the park and starts walking "up and down and round and round"(173), which suggests limited movements in a limited space. These limits are emphasised with the repetition of the same words in the only other order possible: "Round and round and up and down, every day" (176). The narrative of a failed escape also reinforces the closed dimension of the space allowed. The narrator's epiphany only reveals another prison: "We were all walking inside ourselves" (176). Whereas other stories seem to meet a constraining end for a free-wheel narrative, "The Park" does exactly the opposite: the emphatically closed world of the story seems to open up in the last lines with a flight into the world of imagination that goes beyond limits ("And then in the morning the North Wind came, and carried him over seven hills and seven cities", 177), with nature (cherry trees, birds, grass) acting as a bridge. However, if we identify the last paragraph as an allusion to George MacDonald's children's book, At the Back of the North Wind (1871), in which the young hero eventually dies, it is an opening into nothingness that is the alternative to hospital life.

A direct challenge to the traditional emphasis on the ending as culminating point in the story (Tibi 15) seems to be found in "The Secret" that begins with the end ${ }^{14}$-"My eldest sister was called Myrtle" (11): with the verb in the simple past, the incipit suggests that Myrtle no longer exists at the time of the discourse, when the tale is told by the adult narrator. By telling us straight away how it will end, the narrator defeats the usual unfolding of the narrative. On the other hand, "Dossy" features a rare "surprise ending", i.e. "concealing from the reader until the end a fact that would have entirely changed the story" (Gerlach 54). The ending reveals that the happy situation of two children singing together and "hopping and skipping" (51) originally described is imagined by Dossy herself. ${ }^{15}$ The character is standing outside the convent fence, thus occupying a place on the margin of a self-sufficient world, marked by a certain rigidity and no interest in the rest of the world as suggested by the description of the nuns: "their eyes staring right ahead" (52), the nuns, like the teachers and the parents in the other stories, represent constraining authority. Like the other adults, they remain on 
the surface of things: they see a dirty child on her own but cannot imagine the richness and complexity of this child's inner life. In fact, their small-minded vision is governed by their knowledge and appreciation of socio-economic factors: "It's little Dossy Park, they said. With no mother and living in that poky little house in Hart Street and playing by herself all the time, goodness knows what she'll turn out to be" (53). Significantly, the nuns however have the last word. They do so in a literal way as the story ends on their remarks but also in a figurative way: it also ends on their view of things. When the sound of laughter attracts their attention, their perception puts an end to the imagined pair of friends presented so far. The nuns' words take over and cancel the world imagined by Dossy. It is interesting to place Frame's use of the "surprise ending", which is a popular form of closure that belongs to tradition/the past, ${ }^{16}$ in relation with Frame's avowed desire to break away from conventions. Frame in "My Last Story" has the character announce her refusal to write fiction in a conventional way: "I don't like putting he said she said he did she did, and telling about people" (181). Guignery judiciously remarks that in doing so, "[t]he narrator exposes [...] the exhaustion of traditional realism by drawing attention to the narrative conventions, using them and then immediately putting them under erasure" (314). Isn't it significant that Frame should use the "surprise ending", this fairly conventional form in "Dossy" which denounces the narrow-mindedness of those who detain the authority? The criticism of authority suggested in the story seems indeed to extend to the form of the story. ${ }^{17}$ The pattern of the adult as figure of authority appearing at the end can be found in childhood stories like "Treasure" and "My Father's Best Suit". This figure marks the end of the adventure or flight of the imagination depicted in the story. It marks the return to order but is always accompanied with a sense of deflation. ${ }^{18}$ This appearing or reappearing of the figure of authority, usually limiting and constraining, can be read as a metaphor of how Frame regards endings. A counter-example that corroborates this is "Tiger Tiger" where the imagination does not give in to authority and ends on a note of elation with the little girl getting her tiger. The sense of closure derived from the fact that the character obtains what she wishes ${ }^{19}$ is however disrupted by the unlikelihood of the wish being granted. ${ }^{20}$

\section{2. "I select and confect"}

I am borrowing here from A.S. Byatt's autobiographical story, "Sugar" (1987):

I select and confect. What is all this, all this story so far, but a careful selection of things that can be told, things that can be arranged in the light of day? Alongside this fabrication are the long black shadows of the things left unsaid, because I don't want to say them, or dare not, or do not remember, or misunderstood or forgot or never knew (241).

12 Byatt here evokes the two main ideas that will occupy us for the rest of this paper: the self-reflexive dimension of Frame's stories and the narrator's choice to end on a positive note.

13 "Everything is always a story" (131) declares the character of the writer in "Jan Godfrey". ${ }^{21}$ What this means is that Frame acknowledges that everything goes through the filter of narrativisation, of fiction making, of organising the real by selecting from it to confect the text. Of course, this arbitrary organisation of a tale may or may not be revealed. Frame's fiction in general is said to be "pervasively self-reflexive, often metafictional-that is fiction that talks about being fiction, that considers constantly 
the process and contexts of its creation" (Ferrier 12). How does the self-reflexive dimension present in a number of Frame's Lagoon stories illustrate the author's perception of closure?

"The Lagoon" announces closure with the dropping of the curtain as in the theatres where fiction is performed: "And then my aunt dropped the curtain" (7). The gesture, with its analogy with the theatre, emphatically marks the end of the aunt's tale as such. It announces the autodiegetic narrator's reaction: "Was it my aunt speaking or was it my grandmother or my great-grand-mother who loved a white lace dress?" (7). The narrator's questioning of the aunt's tale can be read as an overall questioning of the way we know the past. But the query, which suggests the importance of truth and exactness, is eventually dismissed by the last paragraph that gives ultimate supremacy to the power of imagination through the emphasis on a cross-generational children's game.

The stories that have a writer as a narrator are of course the most self-reflexive. For instance in "Miss Gibson-And the Lumber-Room" the narrator details the construction and selection at work behind the finished essay she produced as a child: "I didn't put him in my essay. I didn't put Marie-Suzanne in either. I saved them up for The Cook and the Gardener [...]" (144). However, no self-reflexivity colours the ending. What happens at the end is that the voice of the adult narrator and the voice of the child-character seem to merge. Whereas the story openly purports to distinguish the true from the false, the real from the fabricated, these distinctions collapse in the concluding paragraph in what Christine Lorre calls "the child-like breathlessness of the prose" $(2007,257)$ marked by the repeated use of the polysyndeton. In a mirror effect with "The Secret" that begins with the end, "My Last Story" famously ends with the beginning. After all the sentences in the negative describing what she will not write, the narrator eventually uses positive forms: "And I'm going to put three dots with my typewriter, impressively, and then I'm going to begin..." (183). As has been remarked, the three dots are the sign of the narrator's "intention to subvert the traditional canons of narrative representations [...] acting as a sort of fissure or gap" (Casertano 349). They mark an opening, they are "the sign of a new departure and not of a closure" (Guignery 315$)^{22}$. Yet, here again, the story ends on an ambiguous note. This story seems to close on a dysphoric ending, with a clausula heavy with negative elements applying to the narrator: "I think I must be frozen inside with no heart to speak of. I think I've got the wrong way of looking at Life" (183). Her negative statements echo what appeared before, notably "My sister has a heart of gold, that's how they express things like that" (183). Yet, whereas the narrator seems to be lamenting her difference from others, the way she distorts the expression "have a heart of gold" and adds a capital letter to "Life" ${ }^{23}$ suggests irony and disregard for limits. Frame's reader is thus left stranded with uncertainties.

In other stories, a reflection on the question of the ending is carried out via the expression by a character of a desire for closure, for a neat whole with a marked ending, preferably a happy one. This is at the core of the stories dealing with lonely people. In "The Day of the Sheep", echoing Nance's helplessness when nothing is as she thinks it should be, the narrative voice declares: "It is always nice to understand the coming and going of a day" (69). In the last paragraph, we read "it would be nice to travel if you knew where you were going and where you would live at the end [...]" (75). Nance feels she has no grasp over her life and her aim is the completion of a 
scheme, a totalising and satisfying whole. Nance is like the lost sheep in the story and these two quotes indicate that she is looking for structure, for enclosure to put an end to her anguish. However if the reader is made to sympathise with Nance's anxiety, the material shape her desire takes lessens this sympathy: "A flat-roofed house and beds with shiny covers, and polished fire-tongs, and a picture of moonlight on a lake" (71). The details are here meant to inform the reader that her aims are very limited and shaped by a desire for conformity and the endorsement of stereotypes. The overall effect is that the wish for an end, in the sense of an organised whole, i.e. the desire for closure, equates with narrow-mindedness and insignificance that prevent her (as shown in the last paragraph) from understanding "the leafless cloudy secret and the sun of any day" (75). Here again, a phrase from the first paragraph reappears to suggest circularity and lack of progress. Desire for closure indicates lack of scope and brings enclosure.

"The Pictures" evokes the question of endings more directly still. Just like Nance, the nameless woman in "The Pictures" is looking for closure and certainties to counteract and evade the loneliness that can be guessed at. These are to be found in the watching of a film that offers the guarantee of a happy ending after a set length of time: "Seven thousand feet, the woman said to herself. She liked to remember the length of a picture, it was something to be sure of" (164). Going to the cinema is presented as comforting: there is indeed a marked contrast between the dark smoothing room where she can indulge herself and cry unseen (164) and "the hard yellow daylight" that makes people coming out of the cinema blink because it is too strong (165). Watching a film is escapism: she prefers to forget her life for the duration of the movie as suggested with the confusion between her and the heroine of the film with the use of the pronoun without a new referent: "She knew she could see the greatest love story in the world till after four o'clock [...] And to know that in the end he would take her out [...]" (164). What is also stressed is the comfort provided by the fact that the end of the film is a foregone conclusion. The film is indeed presented in terms of its closure: its limits, be they of length of actual film material, in terms of time, in terms of labels (the film is comfortably labelled on the posters outside): "It was Life and Love and Laughter, and Tenderness and Tears" (161). The limit applies to the contents too. The most important part in the film is clearly the end that governs the whole film watching: "And to know that in the end he would take her out in the moonlight" (164) later verified when the end of the film actually comes, with insistence on the light of the moon and music (165): a mirror effect to indicate better that it is an enclosed world filled with clichés. In both cases the figure of the polysyndeton enhances the happy ending as a string of clichés. ${ }^{24}$ The happy ending as such is marked by conventions that are detailed:

and in the end they kissed again, and they sailed on the lake, the beautiful lake with the foreign name. It was midnight and in the background you could see their home that had a white telephone in every room, and ferns in pots and marble pillars against the sky, it was lovely (165).

The happy ending is marked by imported material signs of opulence like the white telephone which evoke a Hollywood studio more than New Zealand reality. Conventions are recognised by the audience: "they knew it was the end" (165). Not only is the film ending formally conventional (as they can read the signs) but it is also conventional and conservative in what it edicts as happiness, with its stress on wealth and social success. 
In both "The Day of the Sheep" and "The Pictures", the aspiration to the comforting closure of the ending falls under the tag of cliché, of fear to tackle the real. Indeed, few stories in The Lagoon and Other Stories offer a happy ending, and when they do, the latter is rarely unqualified.

\section{Happy endings are for children}

20 As the narrator of Graham Greene's The End of the Affair suggests, "[a] story has no beginning or end: arbitrarily one chooses that moment of experience from which to look back or from which to look ahead" (7). It seems indeed that the adult narrator of childhood stories deliberately chooses to end her reminiscences on an uplifting note. Christine Lorre remarks that by and large:

Frame's childhood stories look back at a world in which joy and play figure largely, even though they are constantly threatened, and occasionally defeated by loss. Overall, the sunny life that fills, and sometimes overflows in these stories is a way to hold danger and subsequent sadness at bay. ("Narrative Voice" 2011 133).

21 I think this finds an illustration in the ending given to the childhood stories or the state of the child at the end of a story. Critics seem to agree on the unmitigated uplifting ending to "My Cousins-Who Could Eat Cooked Turnips". ${ }^{25}$ Indeed, following the epiphany indicated by "And then we understood" (47), relationships relax between the cousins and with their mother, now laughing: "and everything was all right again" (47). The ending is a picture of harmony. But I would like to argue that, true to what she shows in her other stories representing children, the happy ending is contrived by the adult narrator who never allows the reader to forget it. The reader is indeed invited to put this happy ending in perspective.

"Child" ends on a happy moment: the narrator and her friend are trying the kite Minnie's grandfather has just made and the story stops just when it is going to be Jan's go. It ends on this anticipated pleasure that, because it has not happened, cannot be spoilt nor disappointed. There are elements in the story that refer to death and unstoppable decay ${ }^{26}$ but the narrator's choice is to stop at the moment of climax for the little girl who cannot find suitable words to express her happiness-"Oh, oh, I said because I wanted to say something and there was nothing else to say" (86). But the euphoric state is signalled as a temporary state, just like the childhood enjoyed by the character... Indeed the concluding paragraph includes the child's voice but also marks the return to the adult voice, who had previously been taken over by the child's. ${ }^{27}$ While the child Jan remains on top of the hill, the very last sentence evokes the world below: the daily mundane life that isn't that of freedom and high summits but the one where she comes from and will return to: "And down from the other hill was the place where I lived [...]" (86).

23 As said above "The Secret" begins with the end and announces Myrtle's death but, interestingly, the end actually denies Myrtle's death. The story ends on the child's conviction that "it was all right" (17). In the last paragraph, the narrative voice fluctuates from that of the child with the use of free indirect style to that of the adult narrator. The very last sentence follows the binary rhythm of iambic meter-"And then / I fell / a/sleep" (17)-which conveys reassuring regularity, a regularity that echoes the comforting rhythm of Myrtle's heart beat: "Lub-dub, lub-dub, lub-dub, her heart was saying" (17). Whereas the narrator's comment ("her heart was saying") ominously 
breaks the rhythm, nothing comes to contradict the last sentence apart from its inner dual meaning (suggesting that the child then forgot the warning). So, even though the very last sentence is ambiguous, the overall choice is to foreground an uplifting note, to stop on a euphoric note even if darker elements have been presented before. The child thus falls asleep thinking of the image of blossom and fulfilment that suits her purpose: "I thought tomorrow there'll be a ripe plum on the plum tree, Myrtle and I will eat it" (17). With the fruit coming up to ripeness, the character reassures herself with the belief in the natural cycle of things that she believes is theirs too.

Stories about childhood have a narrative voice that fluctuates between the adult narrator looking back and the child whose voice is recreated through free indirect style. The adult voice is the one who with the benefit of hindsight puts things in perspective and dampens the impact of the child's enthusiasm on the reader. It is the case at the end of "Child", as seen above, and also at the end of "Summer" which concludes on a euphoric note with father and son going in the house together, a picture of love and wordless understanding: the narrator circumscribes the moment of happiness in time-"and I didn't care about the lost ball any more that night" ${ }^{28}$ (140). With the addition of the temporal clause, the narrator suggests that the anguish came back on other nights and thus partly cancels the general well-being depicted in the last sentence.

Happiness seems to be in a large part the prerogative of children. The artificial happy ending featured in the film of "The Pictures" and to which the woman seems to aspire is contrasted by the ending actually given to the story. If the woman returns to her worries when the film is over, the text ends on an image of her happy daughter: "But the little girl in the pixie-cap didn't feel sad, she was eating a paper lolly, it was greenyblue and it tasted like peppermints" (166). Commenting on the very last sentence, Christine Lorre observes that "[t]he child plunges her mother, as well as the reader, straight back into life in a happy colourful and tasty way" ("Unspoken" 2011 58). The last sentence forms a paragraph on its own and it is debatable whether the child's unquestioning happiness and promising appetite for life has an effect on the woman's happiness, formally separated as they are in two different paragraphs articulated by a contrasting "But". The emphasis falls on the simple earthly joys of the little girl (colour, taste, touch) as opposed to the artificial paradise limited in time and place favoured by her adult mother.

Happy endings do appear in Frame's fiction but they have nothing to do with the clichés denounced in the rest of the stories: children are at the centre of these final uplifting notes but the temporariness of their state suggests the transience of the feelings and euphoric atmosphere presented. Adults like Nance in "The Day of the Sheep" and the woman in "The Pictures" on the other hand are caught in conventional aspirations and happy endings that prevent them from being able to enjoy daily life.

Closure in Frame's Lagoon stories is more formal than thematic. Indeed there is often a discrepancy between the ending that is formally foregrounded (often via some apparent circular pattern) and the story that remains indeterminate or contradictory. The overall effect dismisses complete adhesion to a closed pattern. A number of stories actually address the question of the end that usually comes to appear as a crippling totalising whole, thus often precluding any sense of closure or mocking and contradicting the supposed closure achieved. This coexistence of the two different trends or pulls in the same ending is an instance of Frame's taste for the coexistence of 
opposites, which Alice Braun deems to be the sign of a truly poetic vision. ${ }^{29}$ Of the minimalist pieces in the collection, Vanessa Guignery says they "require one to reconsider one's own conception of story-telling" (305). Similarly, for the reader looking for weight and significance in the ending, Frame's early stories in The Lagoon and Other Stories prove an unremittingly challenging experience that defies certainties, an ambiguity that tends to disappear in later-and also longer-stories which offer more definite endings, especially when closing with a representation of death. ${ }^{30}$

\section{BIBLIOGRAPHY}

Bazin, Claire and Alice Braun. Janet Frame, The Lagoon and Other Stories : Naissance d'une œuvre. Paris : PUF-CNED, 2010.

Bazin, Claire. « Histoires drôles et drôles d'histoires ». Textes et Genres 5 (2011) : 9-20.

---. Janet Frame. Tavistock: Northcote Publishers, 2011.

Braun, Alice. “The Sense of an Ending in Janet Frame's Fiction.” Textes et Genres 5 (2011): 97-109.

Byatt, Antonia Susan. "Sugar." In Sugar and Other Stories. London: Penguin, 1987. 215-248.

Casertano, Renata. "Falling Away from the Centre: Centrifugal and Centripetal Dynamics in Janet Frame's Short Fiction." in Telling Stories: Postcolonial Short Fiction in English. Ed. Jacqueline Bardolph. Amsterdam : Rodopi, 2001. 349-356.

Del Lungo, Andrea. L'Incipit Romanesque. 1997. Traduction française. Paris : Seuil, 2003.

Evans, Patrick. “Alienation and the Imagery of Death. The Novels of Janet Frame.” Meanjin Quarterly (Sept 1973): 294-303.

Ferrier, Carole (ed.). The Janet Frame Reader. London: The Women's Press, 1995.

Frame, Janet. The Lagoon and Other Stories. 1951. London: Bloomsbury, 1997.

---. An Angel at My Table. 1989. London: Virago, 2010.

Gerlach, John. Toward the End: Closure and Structure in the American Short Story. Montgomery, Ala.: University of Alabama Press, 1985.

Greene, Graham. The End of the Affair. 1951. London: Penguin, 1962.

Guignery,Vanessa. "Is there a story in Janet Frame's The Lagoon and Other Stories?" Etudes Anglaises. 63:3 (2010): 305-317.

Herrnstein Smith, Barbara. Poetic Closure: A Study of How Poems End. Chicago: University of Chicago Press, 1968.

Lorre, Christine. "The Tropes and Territory of Childhood in The Lagoon and Other Stories (1951) by Janet Frame." In Tropes and Territories: Short Fiction, Postcolonial Readings, Canadian Writings in Context. Ed. Marta Dvorak and W. H. New. Montreal: McGill - Queen's University Press, 2007. 247-269 
---. "Narrative Voice and the Making of the Self: A Study of Janet Frame's The Lagoon and Other Stories." In Chasing Butterflies. Ed. Vanessa Guignery. Paris: Publibook, 2011. 125-144.

---. “The Unspoken in The Lagoon and Other Stories.” Textes et Genres 5 (2011): 47-60.

---. "Secrets in The Lagoon and Other Stories." Commonwealth Essays and Studies 33:2 (Spring 2011): 87-97.

Reid, Ian. The Short Story. 1977. London: Routledge, 1991.

Richards, Ian. “Janet Frame's Songs of Innocence and Experience: 'A Note on the Russian War"'. 2008. 02 March 2013. <http://nofrillsnzlit.angelfire.com/Frame.html>.

Tibi, Pierre. « La Nouvelle : Essai de compréhension d'un genre. » In Aspects de la nouvelle. Ed. Paul Carmignani. Perpignan : Presses Universitaires de Perpignan, 1988. 7-67.

Torgovnick, Mariana. Closure in the Novel. Princeton, N.J.: Princeton University Press, 1981.

Weiss, Allan. "The Form and Function of the Modern Fable in Janet Frame's Short Stories." Commonwealth Essays and Studies 33:2 (Spring 2011): 43-55.

Williams, Mark. “'Tending the ovens': Janet Frame's Politics of Language.” Commonwealth Essays and Studies 33:2 (Spring 2011): 66-77.

Wilson, Janet. "The Lagoon and Other Stories: Storytelling, Metafiction and the Framean Text." Commonwealth Essays and Studies 33:2 (Spring 2011): 124-136.

Winston Rhodes, H. "Janet Frame: A Way of Seeing in The Lagoon and Other Stories." In Critical Essays on the New Zealand Short Story. Ed. Cherry Hankin. Auckland : Heinemann, 1982. 112-131

\section{NOTES}

1. See for instance Reid (59) and Tibi (15).

2. See Reid, 63. "There has been a growing tendency during the present century for short stories to be 'all middle', to avoid structural complications in general and terminal climaxes in particular".

3. See Lorre, "Secrets" 2011, 93.

4. This emphasis on a suspensive state may be announced in a title like "Child" with the zero article preceding a noun.

5. Frame said "My novels are not novels. I wanted to call them explorations" (quoted in Ferrier 19) and it is tempting to say the same of her stories.

6. When discussing "A Note on the Russian War".

7. Mark Williams makes a similar point about Frame's "politics": "The 'politics' of her fiction do not cohere into a singular position" (75).

8. I am using the world "closure" in Herrnstein Smith's restrictive sense, excluding anti-closural endings that are in fact open ones.

9. "[w]hen the ending of a novel clearly recalls the beginning in language, in situation, in the groupings of characters, or in several of these ways, circularity may be said to control the ending" (Torgovnick 13).

10. That is if we accept the title as part of the text rather than as an element of the paratext.

11. For a postcolonial reading of this story, see Lorre 2007, 255-257.

12. "[B]y ending the story on Mrs Michael's words, [Frame] focuses on the false virtue of religious people who claim to have a deeper understanding of the human soul than others, but who side with mockery when it comes to social bonding" (Lorre "Secrets" 2011 90). 
13. Emphasis mine. Also, as Claire Bazin reminds us, "they" is Benveniste's "non-person" ("Histoires" 2011 14).

14. «' [C]ommencer par la fin' signifie ouvrir la narration sur le dénouement de l'histoire racontée, pour reprendre ensuite le fil chronologique des événements en remontant au début »" (Del Lungo 116).

15. Vanessa Guignery identifies this as "a recurring device in Frame's fiction": "building up a world or a story with recognizable components such as characters, place and action [...] and eventually exposing the artefact by taking that world away, erasing it, 'decreating' it and revealing it only existed in the minds of the characters or the narrators" (313).

16. In his chronological study, Gerlach writes "[w]riters' careers were established by such stories" (54) and deals with surprise endings in the chapter devoted to the late nineteenth century (53-60).

17. Talking about Frame's œuvre, Alice Braun generally remarks that "all of Frame's endings [...] grapple in some way with the question of authority in its relation to language" (100), interestingly understanding authority as the "emanation of a disciplinary apparatus" and of "being an author" and thus enforcing order on a narrative.

18. In a later text too, "The Reservoir", parents formally put an end to both the children's adventure and the story by repeating their injunction not to go to the reservoir: adults set limits while children go beyond them. In the last paragraph, the repetition of the same order shows the adults as ignorantly stuck in a pattern while the children have acquired special knowledge and now share a secret specifically by going beyond the limit.

19. The character reaching his goal is the first signal of closure identified by Gerlach (8).

20. See Christine Lorre's reading of "Tiger Tiger" as a "delirious vision" ("Voice" 2011, 131-132).

21. In her Autobiography, Frame refers to reality as "the ore of the polished fiction" (356). And in an interview about the writing of her autobiography, she declared: "I look at everything from the point of view of fiction" and that when writing an autobiography one was "still bound by the choice of words and the shaping of fiction, and that is similar to when one is writing fiction" (quoted in Bazin 2011, 108). For the interlinking or non differenciation of fact and fiction in Frame's writing, see Claire Bazin's work.

22. Janet Wilson offers a different reading, in which the three dots indicate "a cancellation, a deletion of the last story's content" (134).

23. Capital letters are used throughout The Lagoon stories as a sign of distanciation.

24. See "And to know that in the end he would take her out in the moonlight and a band would play and he would kiss her and everything would be all right again" (164) and "It's a wonderful ending, thought the woman. The full moon up there and the lights and music, it is a wonderful ending" (165). Emphasis mine.

25. See Bazin 2010,130-1. Lorre refers to it as "a story with a clearer progression towards a sunny ending" ("Voice" 2011, 136).

26. Jan mentions the death of her own grandfather (83); "the apples from the little apple tree were eaten by birds and fallen in the grass and lost" (82).

27. Christine Lorre notes that "[t]he progression of the story towards a rise of the narrator's adult voice is [...] accompanied by a shift of emphasis, from the realistic (and its 'raw' memories) to the symbolic." ("Voice" 2011, 130).

28. Emphasis mine.

29. See Braun 2010, 56-57.

30. See for instance "Prizes" and "A Sense of Proportion" originally published in The Reservoir: Stories and Sketches (1963). 


\section{ABSTRACTS}

Closure and happy endings are not phrases that immediately come to mind when looking at Janet Frame's stories in her first collection The Lagoon and Other Stories (1951), texts marked by low narrative content and inconclusiveness which nevertheless maintain a formal ending. This paper explores the tension at stake before focusing on the self-reflexive dimension of some stories in relation to Frame's idea of closure. It concludes with a study of the unlikely presence in Frame's early stories of what is often presented as the epitome of closure, i.e. happy endings (as the temporary privilege of childhood).

Complétude et "happy end" ne sont pas des notions que l'on associe a priori aux nouvelles de Janet Frame, textes au contenu narratif faible et fuyant qui maintiennent néanmoins une fin marquée. Cet article explore cette tension par le biais du rôle de la clausule avant de se pencher sur la dimension auto-réflexive de certaines nouvelles et conclut par l'étude des fins heureuses accordées aux récits d'enfance.

\section{INDEX}

Keywords: childhood, childhood stories, clausula, closure, endings, hospital stories, selfreflexivity

Mots-clés: auto-réflexivité, récits d'enfance, enfance, clausule, complétude, fin, récits d'hôpitaux psychiatriques

\section{AUTHORS}

\section{ARMELLE PAREY}

Université de Caen / ERIBIA

Maître de conférences

armelle.parey@unicaen.fr 